\title{
Near-net shape manufacture of B4C-Co and ZrC-Co composites by slip casting and pressureless sintering
}

Ortiz, Angel L. ; Leal, Victor Manuel Candelario; Moreno, Rodrigo; Guiberteau, Fernando

Published in:

Journal of the European Ceramic Society

Link to article, DOI:

10.1016/j.jeurceramsoc.2017.07.024

Publication date:

2017

Document Version

Peer reviewed version

Link back to DTU Orbit

Citation (APA):

Ortiz, A. L., Leal, V. M. C., Moreno, R., \& Guiberteau, F. (2017). Near-net shape manufacture of B C-Co and $\mathrm{ZrC}-\mathrm{Co}$ composites by slip casting and pressureless sintering. Journal of the European Ceramic Society, 37(15), 4577-4584. https://doi.org/10.1016/j.jeurceramsoc.2017.07.024

\section{General rights}

Copyright and moral rights for the publications made accessible in the public portal are retained by the authors and/or other copyright owners and it is a condition of accessing publications that users recognise and abide by the legal requirements associated with these rights.

- Users may download and print one copy of any publication from the public portal for the purpose of private study or research.

- You may not further distribute the material or use it for any profit-making activity or commercial gain

- You may freely distribute the URL identifying the publication in the public portal 
Submitted to Journal of the European Ceramic Society, April 2017. Revised July 2017.

\title{
Near-net shape manufacture of $\mathrm{B}_{4} \mathrm{C}-\mathrm{Co}$ and $\mathrm{ZrC}$-Co composites by slip casting and pressureless sintering
}

\author{
Angel L. Ortiz ${ }^{\text {a,* }}$, Victor M. Candelario ${ }^{\text {b,c }}$, \\ Rodrigo Moreno d, Fernando Guiberteau ${ }^{\text {a }}$
}

${ }^{a}$ Departamento de Ingeniería Mecánica, Energética y de los Materiales, Universidad de Extremadura, 06006 Badajoz, Spain.

${ }^{\mathrm{b}}$ LiqTech International AS, Industriparken 22C, 2750 Ballerup, Denmark.

${ }^{\mathrm{c}}$ Department of Energy Conversion and Storage, Technical University of Denmark, Ris $\varnothing$ Campus, Frederiksborgvej 399, DK-4000 Roskilde, Denmark.

${ }^{d}$ Instituto de cerámica y Vidrio, Consejo Superior de Investigaciones Científicas, 28049 Madrid, Spain.

* Corresponding author:

Angel L. Ortiz

Tel +34 924289600 Ext: 86726

Fax: $\quad+34924289601$

E-mail: alortiz@unex.es

\begin{abstract}
Fabrication of near-net shaped $\mathrm{B}_{4} \mathrm{C}-\mathrm{Co}$ and $\mathrm{ZrC}-\mathrm{Co}$ composites by slip casting and pressureless sintering is described. It is shown how $\mathrm{B}_{4} \mathrm{C}-\mathrm{Co}$ and $\mathrm{ZrC}-\mathrm{Co}$ concentrated suspensions can be prepared by aqueous colloidal processing, and optimized (in terms of $\mathrm{pH}$, deflocculant contents, and sonication time) to have a shear-thinning rheological behaviour suitable for the near-net shaping of the corresponding cermet compacts by slip casting. It is also demonstrated that the robust, highly-dense compacts so obtained have a uniform green microstructure without macrodefects or gradient density, and which can be fully densified by
\end{abstract}


pressureless sintering. Specifically, it is shown that $\mathrm{B}_{4} \mathrm{C}-\mathrm{Co}$ compacts densify by reactive and transient liquid-phase sintering, thus resulting in multi-component ceramics. $\mathrm{ZrC}-\mathrm{Co}$ compacts densify however by persistent liquid-phase sintering, thus resulting in cermets. An explanation is given for these observations, and general implications are discussed for the near-net shape manufacture of these and similar carbide-metal composites for use in engineering applications.

Keywords: cermets; $\mathrm{B}_{4} \mathrm{C}$; $\mathrm{ZrC}$; colloidal processing; pressureless sintering.

\section{Introduction}

Ceramic-metal composites (i.e., cermets) have great interest as structural materials for a broad variety of engineering applications because they appropriately exploit the benefits of the hard ceramic matrix and of the tough metal binder, reason for which they are known with the collective name of "hardmetals", or "cemented carbides" if the ceramic matrix is specifically a refractory carbide [1]. The most widely used and investigated of the hardmetals is $\mathrm{WC}-\mathrm{Co} / \mathrm{Ni}$, but other formulations of cemented carbides are equally possible as long as the metal binder allows the liquid-phase sintering of the carbide. In this context, pure $\mathrm{B}_{4} \mathrm{C}$ and $\mathrm{ZrC}$ are two refractory carbides (a covalent carbide the former, and an interstitial carbide the latter) with great appeal in structural applications [2-4]. Thus for example, owing to their high or ultrahigh hardness, they may find use in the field of contact mechanics and tribology [5-8]. Also, by virtue of its extreme lightness, $\mathrm{B}_{4} \mathrm{C}$ is ideal ceramic armour for both personnel and vehicle protection [9], while, due to its great refractoriness, $\mathrm{ZrC}$ belongs to the short list of ultra-high-temperature ceramics for extreme environment applications [10]. Unfortunately however, the great potential of $\mathrm{B}_{4} \mathrm{C}$ and $\mathrm{ZrC}$ as engineering ceramics is limited by their brittleness and poor pressureless sinterability. This latter also conditions the near-net shape manufacture of $\mathrm{B}_{4} \mathrm{C}$ and $\mathrm{ZrC}$ 
ceramics, as they are best densified with the aid of external pressure (for example using hot pressing, hot-isostatic pressing, or especially spark-plasma sintering) [2,5-8,11-18]. They thus appear to be appropriate candidates for the fabrication of cermets [19-23].

Recently, we have demonstrated that it is possible to obtain robust $\mathrm{B}_{4} \mathrm{C}-\mathrm{Ni}$ compacts by slip casting from $\mathrm{B}_{4} \mathrm{C}-\mathrm{Ni}$ concentrated suspensions prepared by aqueous colloidal processing [23]. This combination of techniques is certainly interesting since aqueous colloidal processing allows the challenging co-dispersion of the ceramic and metal phases in the form of environmentally-friendly suspensions with optimized rheological properties, whereas slip casting allows the subsequent near-net shaping of compacts demanded by industry. A Co binder offers some benefits over Ni binder, for example, in terms of hardness and corrosion resistance [24,25]. The former is very relevant because high hardness is an important attribute of the covalent and interstitial carbides required in many engineering applications, and especially in those within the field of contact mechanics and tribology. Therefore, it seems timely to extend the previous study on $\mathrm{B}_{4} \mathrm{C}-\mathrm{Ni}$ to the potentially appealing $\mathrm{B} 4 \mathrm{C}-\mathrm{Co}$ composite and, in addition, to expand it to the also potentially interesting $\mathrm{ZrC}$-Co composite to thus cover two representative types of different refractory carbides. Moreover, the earlier study on $\mathrm{B}_{4} \mathrm{C}-\mathrm{Ni}$ was devoted exclusively to aspects of aqueous colloidal processing and shaping by slip casting, with no information about sintering, reason by which it also seems timely to conduct additional studies on the $\mathrm{B}_{4} \mathrm{C}-\mathrm{Co}$ and $\mathrm{ZrC}-\mathrm{Co}$ composites of both pressureless sintering and microstructural characterization. These all were indeed the objectives of the present study.

\section{Experimental procedure}

The starting materials used were commercially available $\mathrm{B}_{4} \mathrm{C}\left(>99 \%, d_{50} \sim 0.5 \mu \mathrm{m}, \rho=2.51\right.$ g/cm ${ }^{3}$; Grade HD 20, H.C. Starck, Germany), $\operatorname{ZrC}\left(>99 \%, d_{50} \sim 3-5 \mu \mathrm{m}, \rho=6.7 \mathrm{~g} / \mathrm{cm}^{3}\right.$; Grade B, 
H.C. Starck, Germany), and Co $\left(>99.8 \%, d_{50} \sim 1.6 \mu \mathrm{m}, \rho=8.92 \mathrm{~g} / \mathrm{cm}^{3}\right.$; Alfa Aesar, Germany) powders. They were characterized independently by scanning electron microscopy (SEM; Quanta 3D FEG, FEI, The Netherlands) to confirm the particle sizes indicated by the manufacturers, and by X-ray diffractometry (XRD; D8 Advance, Bruker AXS, Germany) and Xray photoemission spectroscopy (XPS; K-Alpha, Thermo Scientific, UK) to qualitatively examine the phase compositions and the bonding environments or statuses, respectively.

The procedure of aqueous colloidal processing followed the standard protocol. In particular, in a first stage the colloidal stability of the ceramic (i.e., $\mathrm{B}_{4} \mathrm{C}$ and $\mathrm{ZrC}$ ) and metal (i.e., Co) powders was studied individually using dilute suspensions $(0.1 \mathrm{~g} / \mathrm{l})$ with a short equilibrium (i.e., stabilization) time (30 min). To this end, systematic zeta potential measurements (Zetasizer Nano-ZS, Malvern, UK) were first made (in triplicate) as a function of $\mathrm{pH}$ (adjusted within the acidic or basic ranges using $10^{-1} \mathrm{M} \mathrm{HCl}$ or $\mathrm{KOH}$ solution, respectively) on single-phase suspensions prepared without deflocculant using deionized water as suspension medium and $\mathrm{KCl}$ $10^{-2} \mathrm{M}$ as inert electrolyte. Next, additional zeta potential measurements were also made (in triplicate) at natural $\mathrm{pH}$ as a function of the deflocculant content (in the range $0-2.2 \mathrm{wt} . \%$ ). In the three cases, deflocculation was done using commercially available polyelectrolytes, specifically, a synthetic polyelectrolyte of unknown composition (PKV; Produkt KV5088, ZschimmerSchwarz, Germany - it is nonetheless thought to be of type polycarboxylic) for both $\mathrm{B}_{4} \mathrm{C}$ and $\mathrm{ZrC}$, and an ammonium salt of polyacrylic acid with a molecular weight of 2400 and a content of active matter of 35\% (PAA; Duramax ${ }^{\mathrm{TM}}$ D-3005, Rohm \& Haas, USA) for Co.

In a second stage, multi-component concentrated suspensions were prepared in deionized water containing ceramic (either $\mathrm{B}_{4} \mathrm{C}$ or $\mathrm{ZrC}$ ) and metal $(\mathrm{Co})$ in relative concentrations of 80 and 20 vol. \%, respectively. These suspensions were prepared to a total solids loading of 30 vol. $\%$ 
because the earlier study on $\mathrm{B}_{4} \mathrm{C}-\mathrm{Ni}$ indicated that higher solids loadings (in the range $\sim 30-40$ vol.\%) increase the suspension viscosity thus complicating the slip casting performance without improvement of the green-body densification [23]. The suspensions were prepared with continuous vigorous mechanical stirring with helices to ensure correct mixing, using the following protocol of sequential addition. First, the $\mathrm{pH}$ of the deionized water was adjusted to the desired value by dropwise addition of an aqueous solution of $25 \mathrm{wt} . \%$ tetramethylammonium hydroxide (TMAH, Aldrich-Chemie, Germany). Next, the PAA content required to appropriately disperse the Co powder was added, followed by incorporation of the Co powder, stabilization (i.e., equilibration) for $5 \mathrm{~min}$, and sonication for $1 \mathrm{~min}$. Then, the PKV content required to appropriately disperse the ceramic powder was added, followed by addition of the ceramic powder, stabilization for $15 \mathrm{~min}$, and lastly sonication for different times to thus investigate its effect on the rheological behaviour of the suspension. The $\mathrm{pH}$ was maintained at the desired value throughout the entire process.

The rheological behaviour of the $\mathrm{B}_{4} \mathrm{C}-\mathrm{Co}$ and $\mathrm{ZrC}-\mathrm{Co}$ suspensions was studied using a rheometer (Haake Mars, Thermo Fisher Scientific, Germany) operated in controlled shear rate mode. The measuring system consisted of a double-cone and plate, with cone angle of $2^{\circ}$, provided with a cover plate to avoid evaporation. The measurement cycle of the flow curves involved a linear stretch of shear rate increase from 0 to $1000 \mathrm{~s}^{-1}$ in $300 \mathrm{~s}$, then a plateau at 1000 $\mathrm{s}^{-1}$ for $60 \mathrm{~s}$, and lastly a linear decrease to zero shear rate also in $300 \mathrm{~s}$. The thixotropy/rheopexy was determined from the area of the flow curve's hysteresis loop, and the viscosity by direct reading at $1000 \mathrm{~s}^{-1}$ in the uploading stretch.

For the fabrication of the $\mathrm{B}_{4} \mathrm{C}-\mathrm{Co}$ and $\mathrm{ZrC}-\mathrm{Co}$ composites, the corresponding multicomponent concentrated suspensions with appropriate rheological behaviour were next slip cast 
on plaster moulds to obtain compacts (at least 6 specimens per each composition) with different morphology, whose green-body microstructure was examined by SEM after drying in air at room temperature for $48 \mathrm{~h}$ within the moulds. The degree of green-body densification was also evaluated (in triplicate), using to that end $\mathrm{Hg}$ intrusion porosimetry (PoreMaster 60, Quantachrome Instruments, UK). Finally, these compacts were pressureless sintered (1000-3560FP20, Thermal Technology Inc., USA) at $1700{ }^{\circ} \mathrm{C}$ for $2 \mathrm{~h}$ (heating and cooling ramps of 10 and $20{ }^{\circ} \mathrm{C} / \mathrm{min}$, respectively) in a flowing Ar-gas atmosphere of $99.999 \%$ purity. The $1700{ }^{\circ} \mathrm{C}$ temperature was chosen because it ensures the existence of a low-viscosity liquid phase during pressureless sintering given that Co has a melting point of $\sim 1500{ }^{\circ} \mathrm{C}$. Once polished using conventional ceramographic methods, their microstructure was investigated by SEM together with energy-dispersive $\mathrm{X}$-ray spectrometry (EDS) and $\mathrm{XRD}$. The sintered $\mathrm{B}_{4} \mathrm{C}-\mathrm{Co}$ and $\mathrm{ZrC}-\mathrm{Co}$ composites were also broken, and their fracture surface was observed by SEM. The degree of densification of the sintered $\mathrm{B}_{4} \mathrm{C}-\mathrm{Co}$ and $\mathrm{ZrC}-\mathrm{Co}$ composites was evaluated by image analysis of multiple SEM images (taken randomly on both polished and fracture surfaces).

\section{Results and discussion}

Figs. 1 and 2 show representative low- and high-magnification SEM images, respectively, of the $\mathrm{B}_{4} \mathrm{C}, \mathrm{ZrC}$, and $\mathrm{Co}$ starting powders. It can be seen that the particles in the $\mathrm{B}_{4} \mathrm{C}$ powder are equiaxed and have an average size in the submicrometre range (Figs. 1A and 2A). The particles in the $\mathrm{ZrC}$ powder are also equiaxed (although less faceted), but have greater size dispersion. Indeed, there are particles with sizes from the ultrafine range to the micrometre scale (Figs. 1B and 2B). Finally, it can also be seen that the particles in the Co powders have a worn-like morphology, with average length and thickness in the micrometre and submicrometre ranges, respectively (Figs. 1C and 2C). This is because they are actually intergrowths of finer 
particles (Fig. 2C). There is also a rough mat on the surface of the Co particles (Fig. 2C), which is likely a passivating oxide layer. The XRD patterns shown in Fig. 3 indicate that the $\mathrm{B}_{4} \mathrm{C}$ powder contains $\mathrm{B}_{4} \mathrm{C}$ together with $\mathrm{H}_{3} \mathrm{BO}_{3}$ and graphite impurities (very minor phases), that the $\mathrm{ZrC}$ powder contains only $\mathrm{ZrC}$, and that the Co powder contains a combination of $\alpha-\mathrm{Co}$ (fcc) and $\beta$-Co (hcp). Lastly, the XPS spectra shown in Fig. 4 confirm the presence of $\mathrm{H}_{3} \mathrm{BO}_{3}$ in the $\mathrm{B}_{4} \mathrm{C}$ powders, and also indicate that the particles of $\mathrm{ZrC}$ and $\mathrm{Co}$ in the corresponding powders are notably passivated (surface $\mathrm{ZrO}_{2}$ in the former case, and both surface $\mathrm{CoO}$ and $\mathrm{Co}(\mathrm{OH})_{2}$ in the latter case). Unlike what occurs for the solid-state sintering of these refractory carbides, fortunately however these oxidic impurities are not likely to play a dominant role in their densification by liquid-phase sintering.

Fig. 5 shows the variation of the zeta potential against $\mathrm{pH}$ for the individual dilute suspensions of $\mathrm{B}_{4} \mathrm{C}, \mathrm{ZrC}$, and $\mathrm{Co}$. It can be seen that the $\mathrm{B}_{4} \mathrm{C}$ used here has its surface negatively charged within the entire $\mathrm{pH}$ range investigated, always with high absolute values of the zeta potential (approximately in the range $-35 \mathrm{mV}$ to $-60 \mathrm{mV}$ ) [23]. This is attributable to the formation of surface boron oxides and interfacial boron oxycarbides [26,27]. Consequently, this $\mathrm{B}_{4} \mathrm{C}$ will be very stable colloidally in its current state under the vast majority of possible aqueous processing conditions. Note however that other $\mathrm{B}_{4} \mathrm{C}$ powders, even from the same supplier, exhibited zeta potential curves in aqueous media with an isoelectric point at $\mathrm{pH}$ in the range 5-6 [28], which is likely due to their different grades making them to behave differently. It can also be seen that $\mathrm{ZrC}$ has its isoelectric point at $\mathrm{pH} \sim 3.4$, above which the $\mathrm{ZrC}$ particles are already negatively charged. This reflects the surface passivation of the $\mathrm{ZrC}$ particles [29]. This $\mathrm{ZrC}$ reaches high absolute zeta potential values (i.e., $-30 \mathrm{mV}$ ) for $\mathrm{pHs}$ greater than $\sim 6$, above which its colloidal stability in water seems to be ensured. Finally, it can be seen that Co has its 
isoelectric point at $\mathrm{pH} \sim 8.3$, exhibiting an abrupt change from positive to negative zeta potentials. This is attributable to the surface passivation of the Co particles [29]. Above $\mathrm{pH} \sim 8.5$, and particularly at $\mathrm{pH} \sim 10$, Co exhibits zeta potentials high enough (i.e., $-30 \mathrm{mV}$ ) to ensure its colloidal stability in water. Considering this set of results, it seems clear that $\mathrm{pHs}$ above 8.5 are required to prepare the multi-component $\mathrm{B}_{4} \mathrm{C}-\mathrm{Co}$ and $\mathrm{ZrC}-\mathrm{Co}$ suspensions in the absence of deflocculants, with $\mathrm{pH} \sim 10$ being optimum. However, as will be described next, anionic polyelectrolytes were also used to improve the dispersion at $\mathrm{pH} 10$ by shifting the isoelectric points towards more acidic pHs.

Fig. 6 shows the variation of the zeta potential against deflocculant content for the individual dilute suspensions of $\mathrm{B}_{4} \mathrm{C}, \mathrm{ZrC}$, and $\mathrm{Co}$, at their natural $\mathrm{pH}$. Deflocculation of both $\mathrm{B}_{4} \mathrm{C}$ and $\mathrm{ZrC}$ was done using $\mathrm{PKV}$ because it is suitable for carbides [23,30-32], whereas Co was deflocculated using PAA because it has been found to be more appropriate for metals $[23,33]$. It can be seen that both $\mathrm{B}_{4} \mathrm{C}$ and $\mathrm{ZrC}$ always exhibit negative zeta potentials. This was to be expected for $\mathrm{B}_{4} \mathrm{C}$ (which has negative zeta potentials over the entire $\mathrm{pH}$ range), and in the case of $\mathrm{ZrC}$ is understandable considering that the natural $\mathrm{pH}$ is higher than the isoelectric point (i.e., 6.1 vs. 3.4). In both cases the zeta potential increases in magnitude with the PKV addition, but the increase is more marked for $\mathrm{ZrC}$ (from $-33 \mathrm{mV}$ to $-48 \mathrm{mV}$, and therefore $\sim 45.5 \%$ increase) than for $\mathrm{B}_{4} \mathrm{C}$ (from $-47 \mathrm{mV}$ to $-55 \mathrm{mV}$, and therefore $17 \%$ increase). Moreover, the zeta potentials of both $\mathrm{B}_{4} \mathrm{C}$ and $\mathrm{ZrC}$ are already stabilized (at -55 and $-48 \mathrm{mV}$, respectively) for a PKV addition of $1 \mathrm{wt} . \%$, an amount that will be used to deflocculate the ceramic particles in the multi-component concentrated suspensions. The effect of the deflocculant addition is much more pronounced in the case of Co. Its zeta potential changes from positive to negative values with increasing PAA content up to $\sim 0.3 \mathrm{wt} . \%$, attributable to the natural $\mathrm{pH}$ being lower than the 
isoelectric point (i.e., 7.7 vs. 8.3), and then continues to increase in absolute value until it stabilizes (at $-32 \mathrm{mV}$ ) for a PAA addition of $1 \mathrm{wt} . \%$. The metal particles in the multi-component concentrated suspensions will therefore be deflocculated using $1 \mathrm{wt} \%$ PAA.

Multi-component concentrated suspensions of $\mathrm{B} 4 \mathrm{C}-\mathrm{Co}$ and of $\mathrm{ZrC}-\mathrm{Co}$ were then prepared at $\mathrm{pH} 10$ to a total solids loading of 30 vol.\%, whose formulation contains 80 vol. $\%$ ceramic (deflocculated with 1 wt.\% PKV) and 20 vol.\% metal (deflocculated with 1 wt.\% PAA). Fig. 7 shows the flow curves of those $\mathrm{B} 4 \mathrm{C}-\mathrm{Co}$ and $\mathrm{ZrC}-\mathrm{Co}$ suspensions as a function of the sonication time. It can be seen in Fig. 7A that the flow curves of the $\mathrm{B} 4 \mathrm{C}-\mathrm{Co}$ suspensions are very similar, and indicative of shear-thinning rheological behaviour. This is the desirable behaviour because the suspension viscosity under rest conditions is high enough to avoid settling and therefore to ensure proper storage, but low enough under manufacturing conditions to flow appropriately and thus facilitate the shaping of the piece [34]. The suspension viscosity is in the range $\sim 32-35 \mathrm{mPa} \cdot \mathrm{s}$ at a shear rate of $1000 \mathrm{~s}^{-1}$, and the slight difference between the suspensions prepared is simply that those without sonication and sonicated for 1 min exhibit some thixotropy $\left(\sim 1160\right.$ and $660 \mathrm{~Pa} \cdot \mathrm{s}^{-1}$, respectively) while the one sonicated for 2 min exhibits very little

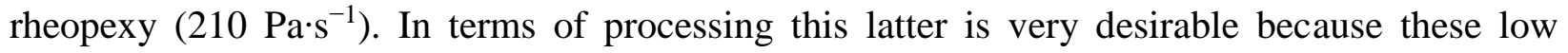
thixotropy or rheopexy values indicate that there is no formation or destruction of structures in the suspension. The rheological behaviour of the $\mathrm{ZrC}-\mathrm{Co}$ suspensions is somewhat different to that of the $\mathrm{B}_{4} \mathrm{C}-\mathrm{Co}$ suspensions. Thus, it can be seen in Fig. $7 \mathrm{~B}$ that, like the $\mathrm{B}_{4} \mathrm{C}-\mathrm{Co}$ suspensions, they all exhibit the desirable shear-thinning rheological behaviour, but in all cases with rheopexy (in the range $\sim 2450-2990 \mathrm{~Pa} \cdot \mathrm{s}^{-1}$ ). Also, there is now a greater difference of viscosity between the suspensions prepared without $(\sim 40 \mathrm{mPa} \cdot \mathrm{s})$ and with sonication (for 1,2 , or $3 \mathrm{~min}$ ), these latter three being almost equally viscous (in the range $\sim 29-31 \mathrm{mPa} \cdot \mathrm{s}$ ). Lastly, the 
comparison between the $\mathrm{B} 4 \mathrm{C}-\mathrm{Co}$ and $\mathrm{ZrC}-\mathrm{Co}$ suspensions indicates that they have similar viscosity for the same preparation condition (difference less than $6 \mathrm{mPa} \cdot \mathrm{s}$ ), although the former have flow curves with less hysteresis loop. This is most likely attributable to the larger size of the $\mathrm{ZrC}$ particles $\left(\mathrm{B}_{4} \mathrm{C}\right.$ with submicrometre size, but $\mathrm{ZrC}$ with micrometre size) favouring the formation of structures in the suspension. Another interesting difference between the $\mathrm{B}_{4} \mathrm{C}-\mathrm{Co}$ and $\mathrm{ZrC}-\mathrm{Co}$ suspensions is that the flow curves of the former shows evidence of a yield point because the shear stress increases first very abruptly and later gradually with increasing shear rate, which is something not observed in the flow curves of the latter in which the shear stress always increases progressively. Therefore, the $\mathrm{B}_{4} \mathrm{C}-\mathrm{Co}$ suspensions exhibit very shear-thinning rheological behaviour (i.e., plastic behaviour), whereas the $\mathrm{ZrC}-\mathrm{Co}$ suspensions exhibit only shear-thinning rheological behaviour (i.e., pseudo-plastic behaviour).

The $\mathrm{B}_{4} \mathrm{C}-\mathrm{Co}$ and of $\mathrm{ZrC}-\mathrm{Co}$ suspensions prepared here all have a rheological behaviour suitable for the near-net shaping of the corresponding compacts by slip casting. Their 30 vol.\% solids loading is also entirely adequate because in slip casting both shaping and consolidation occur simultaneously since the driving force for the wall formation is the filtration through a permeable mould, so that the solids loading is not as critical as in other direct consolidation methods in which the drying stage is performed after the consolidation stage. Thus for example, the $\mathrm{B}_{4} \mathrm{C}-\mathrm{Co}$ and $\mathrm{ZrC}-\mathrm{Co}$ suspensions sonicated for 2 and $3 \mathrm{~min}$, respectively, were slip cast on plaster moulds with different shapes. Fig. 8 shows photographs of some resulting green compacts once dried in air at room temperature for $48 \mathrm{~h}$. Apparently the green compacts did not shrink laterally during drying, which is because water elimination occurs by filtration (i.e., drainage assisted by capillary forces). They are robust and have good handling and storage characteristics. Also, these green compacts of $\mathrm{B}_{4} \mathrm{C}-\mathrm{Co}$ and $\mathrm{ZrC}-\mathrm{Co}$ have high relative densities of $\sim 58$ and $52 \%$, 
respectively, achieved without the application of external pressure. The $\mathrm{B}_{4} \mathrm{C}-\mathrm{Co}$ compacts have higher green-body densification, which is due to the smaller size of the $\mathrm{B}_{4} \mathrm{C}$ particles favouring tighter packaging. Fig. 9 shows representative low- and high-magnification SEM images of the fracture surface of the $\mathrm{B}_{4} \mathrm{C}-\mathrm{Co}$ and $\mathrm{ZrC}-\mathrm{Co}$ compacts in their as-cast condition. It can be seen that the green compacts exhibit a uniform microstructure, with no evidence of macrodefects or density gradients (Figs. 9A and 9C). Moreover, the particles are well packed, and the aggregates of metal particles are homogeneously distributed among the ceramic particles (Figs. 9B and 9D), especially in the case of the $\mathrm{ZrC}-\mathrm{Co}$ compacts due to the larger size of the $\mathrm{ZrC}$ particles. The metal aggregates in the $\mathrm{B}_{4} \mathrm{C}-\mathrm{Co}$ compacts can have $\mathrm{B}_{4} \mathrm{C}$ particles entrapped, which is due to the smaller size of the $\mathrm{B}_{4} \mathrm{C}$ particles.

Fig. 10 shows representative low- and high-magnification SEM images, and Fig. 11 the XRD patterns, of the $\mathrm{B}_{4} \mathrm{C}-\mathrm{Co}$ and $\mathrm{ZrC}-\mathrm{Co}$ composites obtained by pressureless sintering at 1700 ${ }^{\circ} \mathrm{C}$ for $2 \mathrm{~h}$ in $\mathrm{Ar}$ atmosphere. It can be seen in Figs. $10 \mathrm{~A}$ and $10 \mathrm{~B}$ that the $\mathrm{B}_{4} \mathrm{C}-\mathrm{Co}$ composite is fully dense, that it has shrunk preserving the shape ( $18 \%$ lateral shrinkage), and that its microstructure consists of submicrometre grains embedded in an intergranular phase plus large pockets of an additional secondary phase. Clearly, densification occurs by liquid-phase sintering. Also, relative to the un-sintered composite, the XRD pattern in Fig. $11 \mathrm{~A}$ indicates that the $\mathrm{H}_{3} \mathrm{BO}_{3}$ and $\mathrm{C}$ peaks disappeared, that the $\mathrm{B}_{4} \mathrm{C}$ peaks modified their relative intensities and shifted toward larger diffraction angles, and that $\mathrm{CoB}$ and $\mathrm{Co}_{2} \mathrm{~B}$ peaks appeared (with some shifting), this latter compound with marked crystallographic texture. The EDS compositional analyses revealed that the $\mathrm{Co}: \mathrm{B}$ ratio in the pockets is close to 2 , with the presence of $\mathrm{C}$ and $\mathrm{O}$ atoms. With all this information, it is then reasonable to infer that basically the grains are C-richer $\mathrm{B}_{4} \mathrm{C}$, that the intergranular phase is $\mathrm{CoB}$, and that the secondary-phase pockets are textured single- 
crystal $\mathrm{Co}_{2} \mathrm{~B}$ with $\mathrm{C}$ and $\mathrm{O}$ solutes. This reflects the occurrence of reactions between $\mathrm{B}_{4} \mathrm{C}$ (and $\mathrm{H}_{3} \mathrm{BO}_{3}$ as well) and Co during pressureless sintering, which has also been observed during the spark-plasma sintering of $\mathrm{B}_{4} \mathrm{C}$ with $\mathrm{Ti}-\mathrm{Al}$ intermetallics [35]. Moreover, the formation of the $\mathrm{Co}_{2} \mathrm{~B}$ pockets is consistent with the existence in the compacts of Co micrometre aggregates with $\mathrm{B}_{4} \mathrm{C}$ entrapped. Lastly, another interesting conclusion is that the sintered composite is not a cermet, but a multi-component ceramic because under the present sintering conditions Co indeed acted as a reactive and transient liquid phase.

Additionally, it can be seen in Figs. 10C and 10D that the $\mathrm{ZrC}-\mathrm{Co}$ composite is fully dense as well, and that it has shrunk preserving the shape ( $15 \%$ lateral shrinkage). According to its XRD pattern in Fig. 11B, this composite only contains $\mathrm{ZrC}$ and Co. Therefore, it is a cermet with the typical microstructure of the cemented carbides, in particular with $\mathrm{ZrC}$ grains homogeneously embedded in a Co intergranular phase which acted as a persistent liquid phase. This is different from what has been observed earlier in $\mathrm{ZrC}-\mathrm{Mo}$ composites, in which Mo acted as a reactive and transient liquid phase, thus with extensive formation of $\mathrm{MoC}_{2}$ occurring [21,22]. Also, as expected for densification by conventional liquid-phase sintering, the microstructure in Figs. 10C and 10D shows evident signs of grain shape accommodation and grain growth by solution-reprecipitation.

Fig. 12 shows representative SEM images of the fracture surface of the $\mathrm{B}_{4} \mathrm{C}-\mathrm{Co}$ and $\mathrm{ZrC}-\mathrm{Co}$ composites obtained by pressureless sintering at $1700{ }^{\circ} \mathrm{C}$ for $2 \mathrm{~h}$ in $\mathrm{Ar}$ atmosphere. It is evident that there is a vast difference in the fracture mode of the two composites. Specifically, the $\mathrm{ZrC}-\mathrm{Co}$ cermet exhibits many cleavage steps, which is not the case for the $\mathrm{B}_{4} \mathrm{C}-\mathrm{Co}$ composite. Thus, while the $\mathrm{ZrC}-\mathrm{Co}$ cermet has broken in transgranular fracture mode, the $\mathrm{B}_{4} \mathrm{C}-$ Co composite did so in intergranular fracture mode. This difference is mostly attributable to the 
coarseness of the microstructure promoting transgranular fracture in the $\mathrm{ZrC}-\mathrm{Co}$ cermet. Indeed, earlier observations support this explanation, showing that the $\mathrm{ZrC}[6,11]$ ceramics and the $\mathrm{ZrC}-$ $\mathrm{MoSi}_{2}$ [8] and $\mathrm{ZrC}-\mathrm{SiC}$ [13] composites, as well as other ceramics [36], also break transgranularly when their grain size is coarse, but intergranularly, or intergranularly plus transgranularly, when their grain size is sufficiently fine. Nonetheless, composition also plays a role in the fracture mode because the $\mathrm{B}_{4} \mathrm{C}[12,16,18]$ ceramics and the $\mathrm{B}_{4} \mathrm{C}-\mathrm{SiC}[14]$ and $\mathrm{B}_{4} \mathrm{C}-$ SiC-C [14] composites essentially break transgranularly, regardless of the grain size.

To conclude, it is convenient to discuss some final considerations for the near-net shape manufacture of these, and similar, carbide-metal composites by slip casting and pressureless sintering. Specifically, the pressureless sintering cycle (i.e., heating/cooling ramps, temperature, soaking time, and atmosphere) could be customized to thus control the particle sizes in the final microstructure. Customization of the sintering cycle might also force the densification to occur with a persistent liquid phase or with a reactive and transient liquid phase, thus enabling the controlled fabrication of either ceramic composites or cermets. The ceramic:metal ratio in the powder mixtures could also be customized with a view to controlling the volume fraction of intergranular phase (persistent liquid-phase sintering) or secondary phases (reactive and transient liquid-phase sintering), and perhaps the type of microstructure as well (i.e., disconnected-liquid microstructure or connected-liquid microstructure). Beyond compositional aspects (exact type of carbide and metal used), it seems clear that it is potentially possible to fabricate an ample variety of different carbide-metal composites with microstructures, and therefore mechanical properties, tailored for engineering applications. Exploration of this variety of possibilities remains pending, however, for future work. Future research efforts should also be aimed at avoiding the undesirable formation of secondary-phase pockets in the final microstructure when densification 
takes places by reactive and transient liquid-phase sintering. This requires, in general, a greater optimization of the ceramic-metal dispersion, using colloidal processing techniques or other possible alternatives. Nonetheless, it also seems that the secondary-phase pockets will be unlikely to form if the ceramic starting powder is coarser than the metal starting powder, or if the volume fraction of metal in the powder mixture is judiciously reduced. Investigation of these aspects also merits future work.

\section{Conclusions}

Near-net shaped $\mathrm{B}_{4} \mathrm{C}-\mathrm{Co}$ and $\mathrm{ZrC}-\mathrm{Co}$ composites have been manufactured by slip casting from aqueous colloidal suspensions, and subsequent pressureless sintering. Based on the experimental results and analyses, the following conclusions can be drawn:

1. Concentrated suspensions of both $\mathrm{B}_{4} \mathrm{C}-\mathrm{Co}$ and $\mathrm{ZrC}-\mathrm{Co}$ can be prepared by aqueous colloidal processing having a shear-thinning rheological behaviour suitable for slip casting. Advisable preparation conditions for such suspensions are high pHs (i.e., $\mathrm{pH}$ 10), moderate deflocculant contents (i.e., $~ 1$ wt. $\%$ for both the ceramic and the metal), and short sonication times (i.e., 1-2 min). The most critical preparation aspect is the correct dispersion of the metal particles.

2. Robust, highly-dense $\mathrm{B}_{4} \mathrm{C}-\mathrm{Co}$ and $\mathrm{ZrC}-\mathrm{Co}$ compacts can be shaped by slip casting. These green bodies have good handling and storage characteristics, and possess a uniform microstructure without macrodefects or density gradients.

3. The $\mathrm{B}_{4} \mathrm{C}-\mathrm{Co}$ and $\mathrm{ZrC}-\mathrm{Co}$ compacts can be fully densified by pressureless liquid-phase sintering, preserving their shape. Under the present heat-treatment conditions (i.e., 1700 ${ }^{\circ} \mathrm{C}$ for $2 \mathrm{~h}$ in Ar atmosphere) the former densify by reactive and transient liquid-phase 
sintering resulting in multi-component ceramics, and the latter by persistent liquid-phase sintering resulting in cermets.

Acknowledgements This work was supported by the Ministerio de Economía y Competitividad (Government of Spain) and FEDER Funds under Grants nº MAT2013-41012-P and MAT2016-78700-R. Financial support from the Junta de Extremadura under Grant $\mathrm{n}^{\mathbf{o}}$ GR15078, also co-financed with FEDER Funds, is gratefully acknowledged as well. Thanks are also due to Dr Fernando Rodríguez-Rojas for the assistance provided with some dilute suspensions. 


\section{References}

1) P. Ettmayer, Hardmetals and cermets, Ann. Rev. Mater. Sci. 19 (1989) 145-164.

2) F. Thevenot, Boron carbide-a comprehensive review, J. Eur. Ceram. Soc. 6 (1990) 205-225.

3) V. Domnich, S. Reynaud, R.A. Haber, M. Chhowalla, Boron carbide: structure, properties, and stability under stress, J. Am. Ceram. Soc. 94 (2011) 3605-3628.

4) K. Upadhya, J.-M. Yang, W.P. Hoffman, Materials for ultrahigh temperature structural applications, Am. Ceram. Soc. Bull. 76 (1997) 51-56.

5) B. Núñez-González, A.L. Ortiz, F. Guiberteau, N.P. Padture, Effect of $\mathrm{MoSi}_{2}$ content on the lubricated sliding-wear resistance of ZrC-MoSi 2 composites, J. Eur. Ceram. Soc. 31 (2011) $877-882$.

6) D. Bertagnoli, O. Borrero-López, F. Rodríguez-Rojas, F. Guiberteau, A.L. Ortiz, Effect of processing conditions on the sliding-wear resistance of $\mathrm{ZrC}$ triboceramics fabricated by spark-plasma sintering, Ceram. Inter 41 (2015) 15278-15282.

7) B.M. Moshtaghioun, D. Gómez-García, A. Domínguez-Rodríguez, R.I. Todd, Abrasive wear rate of boron carbide ceramics: influence of microstructural and mechanical aspects on their tribological response, J. Eur. Ceram. Soc. 36 (2016) 3925-3928.

8) E. Sánchez-González, O. Borrero-López, F. Guiberteau, A.L. Ortiz, Microstructural effects

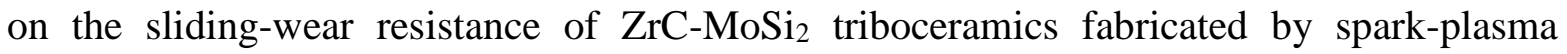
sintering, J. Eur. Ceram. Soc. 36 (2016) 3091-3097.

9) S. Leo, C. Tallon, G.V. Franks, Near-net-shaping methods for ceramic elements of (body) armor systems, J. Am. Ceram. Soc. 97 (2014) 3013-3033.

10) E. Wuchina, E. Opila, M. Opeka, W. Fahrenholtz, I. Talmy, UHTCs: ultra-high temperature ceramic materials for extreme environment applications, Interface 16 (2007) 30-36. 
11) B. Núñez-González B, A.L. Ortiz, F. Guiberteau, M. Nygren, Improvement of the sparkplasma-sintering kinetics of $\mathrm{ZrC}$ by high-energy ball-milling, J. Am. Ceram. Soc. 95 (2012) $453-456$.

12) B.M. Moshtaghioun, F.L. Cumbrera-Hernández, D. Gómez-García, S. de Bernardi-Martín, A. Domínguez-Rodríguez, A. Monshi, M.H. Abbasi, Effect of spark plasma sintering parameters on microstructure and room-temperature hardness and toughness of fine-grained boron carbide (B 4 C), J. Eur. Ceram. Soc. 33 (2013) 361-369.

13) B. Núñez-González, A.L. Ortiz, F. Guiberteau, M. Nygren, Spark-plasma-sintering kinetics of $\mathrm{ZrC}-\mathrm{SiC}$ powder mixtures subjected to high-energy co-ball-milling, Ceram. Int. 39 (2013) 9691-9697.

14) B.M. Moshtaghioun, A.L. Ortiz, D. Gómez-García, A. Domínguez-Rodríguez, Toughening of super-hard ultra-fine grained $\mathrm{B}_{4} \mathrm{C}$ densified by spark-plasma sintering via SiC addition, J. Eur. Ceram. Soc. 33 (2013) 1395-1401.

15) B.M. Moshtaghioun, F.L. Cumbrera-Hernández, A.L. Ortiz, M. Castillo-Rodríguez, D. Gómez-García, Additive-free superhard $\mathrm{B}_{4} \mathrm{C}$ with ultrafine-grained dense microstructures, J. Eur. Ceram. Soc. 34 (2014) 841-848.

16) B.M. Moshtaghioun, A.L. Ortiz, D. Gómez-García, A. Domínguez-Rodríguez, Densification of $\mathrm{B}_{4} \mathrm{C}$ nanopowder with nanograin retention by spark-plasma sintering, J. Eur. Ceram. Soc. 35 (2015) 1991-1998.

17) R. Cano-Crespo, B.M. Moshtaghioun, D. Gómez-García, A. Domínguez-Rodríguez, M. Lagos, Mechanical instability of stressed grain boundaries during plastic deformation of zirconium carbide, J. Eur. Ceram. Soc. 36 (2016) 2235-2240. 
18) B.M. Moshtaghioun, D. Gómez-García, A. Domínguez-Rodríguez, R.I. Todd, Grain size dependence of hardness and fracture toughness in pure near fully-dense boron carbide ceramics, J. Eur. Ceram. Soc. 36 (2016) 1829-1834.

19) H.J.Hamjian, W.G. Lidman, Boron carbide as a base material for a cermet, J. Am. Ceram. Soc. 35 (1952) 44-48.

20) D.C. Halverson, A.J. Pyzik, I.A. Aksay, W.E. Snowden, Processing of boron carbidealuminum composites, J. Am. Ceram. Soc. 72 (1989) 775-780.

21) S.E. Landwehr, G.E. Hilmas, W. G. Fahrenholtz, I.G. Talmy, Processing of ZrC-Mo cermets for high-temperature applications, part I: chemical interactions in the $\mathrm{ZrC}-\mathrm{Mo}$ system, J. Am. Ceram. Soc. 90 (2007) 1998-2002.

22) S.E. Landwehr, G.E. Hilmas, W. G. Fahrenholtz, I.G. Talmy, Processing of ZrC-Mo cermets for high-temperature applications, part II: pressureless sintering and mechanical properties, J. Am. Ceram. Soc. 91 (2008) 873-878

23) F. Rodríguez-Rojas, R. Moreno, F. Guiberteau, A.L. Ortiz, Aqueous colloidal processing of near-net shape B ${ }_{4}$ C-Ni cermet compacts, J. Eur. Ceram. Soc. 36 (2016) 1915-1921.

24) W.M. Daoush, H.S. Park, K.H. Lee, S.F. Moustafa, S.H. Hong, Effect of binder compositions on microstructure, hardness and magnetic properties of (Ta, $\mathrm{Nb}) \mathrm{C}-\mathrm{Co}$ and (Ta,Nb)C-Ni cemented carbides, Int. J. Refract. Met. Hard. Mater. 27 (2009) 669-675.

25) Z. Guo, J. Xiong, W. Wan, G. Dong, M. Yang, Effect of binder content on the erosive wear of $\mathrm{Ti}(\mathrm{C}, \mathrm{N})$-based cermet in $\mathrm{SiO}_{2}$ particle-containing simulated seawater, Int. J. Appl. Ceram. Tech. 11 (2014) 1045-1053.

26) P.D. Williams, D.D Hawn, Aqueous dispersion and slip casting of boron carbide powder: effect of pH and oxygen content, J. Am. Ceram. Soc. 74 (1991) 1614-1618. 
27) X. Li, D. Jiang, J. Zhang, Q. Lin, Z. Chen, Z. Huang, The dispersion of boron carbide powder in aqueous media, J. Eur. Ceram. Soc. 33 (2013) 1655-1663.

28) S. Leo, C. Tallon, G.V. Franks, Aqueous and Nonaqueous Colloidal Processing of Difficultto-Densify Ceramics: Suspension Rheology and Particle Packing, J. Am. Ceram. Soc. 97 (2014) 3807-3817.

29) M. Kosmulski, Isoelectric points and points of zero charge of metal (hydr)oxides: 50 years after Parks' review, Adv. Colloid. Interface Sci. 238 (2016) 1-61.

30) V.M. Candelario, M.I. Nieto, F. Guiberteau, R. Moreno, A.L. Ortiz, Aqueous colloidal processing of $\mathrm{SiC}$ with $\mathrm{Y}_{3} \mathrm{Al}_{5} \mathrm{O}_{12}$ liquid-phase sintering additives, J. Eur. Ceram. Soc. 33 (2013) 1685-1694.

31) V.M Candelario, R. Moreno, Z. Shen, A.L. Ortiz, Aqueous colloidal processing of nano-SiC and its nano- $\mathrm{Y}_{3} \mathrm{Al}_{5} \mathrm{O}_{12}$ liquid-phase sintering additives with carbon nanotubes, J. Eur. Ceram. Soc. 35 (2015) 3363-3368.

32) V.M. Candelario, R. Moreno, R.I. Todd, A.L. Ortiz, Liquid-phase assisted flash sintering of SiC from powder mixtures prepared by aqueous colloidal processing, J. Eur. Ceram. Soc. 37 (2017) 485-498.

33) A.J Sánchez-Herencia, N. Hernández, R. Moreno, Rheological behavior and slip casting of $\mathrm{Al}_{2} \mathrm{O}_{3}$-Ni aqueous suspensions, J. Am. Ceram. Soc. 89 (2006) 1890-1896.

34) R. Moreno, Reología de suspensiones cerámicas, Madrid, Spain: Consejo Superior de Investigaciones Científicas; 2005.

35) W. Ji, R.I. Todd, W. Wang, H. Wang, Z. Fu, Transient liquid phase spark plasma sintering of $\mathrm{B}_{4} \mathrm{C}$-based ceramics using Ti-Al intermetallics as sintering aid, J. Eur. Ceram. Soc. 36 (2016) 2419-2426. 
36) O. Borrero-López, A.L. Ortiz, A.D. Gledhill, F. Guiberteau, T. Mroz, L.M. Goldman, N.P. Padture, Microstructural effects on the sliding wear of transparent magnesium-aluminate spinel, J. Eur. Ceram. Soc. 32 (2012) 3143-3149. 


\section{Figure Captions}

Figure 1. Representative low-magnification SEM images of the (A) $\mathrm{B}_{4} \mathrm{C}$, (B) $\mathrm{ZrC}$, and (C) Co particles in the starting powders.

Figure 2. Representative high-magnification SEM images of the (A) $\mathrm{B} 4 \mathrm{C}$, (B) $\mathrm{ZrC}$, and (C) Co particles in the starting powders.

Figure 3. $\mathrm{XRD}$ patterns of the $\mathrm{B}_{4} \mathrm{C}, \mathrm{ZrC}$, and $\mathrm{Co}$ starting powders. Peak assignations are included.

Figure 4. High-resolution XPS spectra of the $\mathrm{B}_{4} \mathrm{C}, \mathrm{ZrC}$, and $\mathrm{Co}$ starting powders. Core-levels monitored in each case are indicated. Peak assignations are included too.

Figure 5. Evolution of the zeta potential of the dilute suspensions of the $\mathrm{B}_{4} \mathrm{C}, \mathrm{ZrC}$, and $\mathrm{Co}$ starting powders as a function of $\mathrm{pH}$.

Figure 6. Evolution of the zeta potential of the dilute suspensions of the $\mathrm{B}_{4} \mathrm{C}, \mathrm{ZrC}$, and $\mathrm{Co}$ starting powders as a function of the deflocculant content (PKV for both $\mathrm{B}_{4} \mathrm{C}$ and $\mathrm{ZrC}$, and $\mathrm{PAA}$ for $\mathrm{Co}$ ) at the natural $\mathrm{pHs}$.

Figure 7. Flow curves of the concentrated suspensions of (A) 80 vol. $\%$ B 4 C +20 vol. $\%$ Co and (B) 80 vol. $\% \mathrm{ZrC}+20$ vol. $\%$ Co prepared to a total solids loading of 30 vol.\%, without and with 
different sonication times. Sonication was not prolonged further once the flow curve worsened. The arrows indicate the uploading and downloading stretches of the flow curves.

Figure 8. Photographs of various $\mathrm{B}_{4} \mathrm{C}-\mathrm{Co}$ and $\mathrm{ZrC}-\mathrm{Co}$ compacts obtained by slip casting. Photographs were taken after drying in air at room temperature for $48 \mathrm{~h}$.

Figure 9. Representative SEM images of the fracture surface of the $\mathrm{B}_{4} \mathrm{C}-\mathrm{Co}$ compact at (A) lowand (B) high-magnification as well as of the $\mathrm{ZrC}-\mathrm{Co}$ compact at (C) low- and (D) highmagnification. The insets in (B) and (D) are SEM images taken with backscattered electrons.

Figure 10. Representative SEM images of the polished surface of the $\mathrm{B}_{4} \mathrm{C}-\mathrm{Co}$ composite at (A) low- (A) and (B) high-magnification as well as of the $\mathrm{ZrC}-\mathrm{Co}$ composite at (C) low- and (D) high-magnification. The two composites were obtained by pressureless sintering at $1700{ }^{\circ} \mathrm{C}$ for 2 $\mathrm{h}$ in $\mathrm{Ar}$ atmosphere. The insets in (A) and (C) compare the as-cast and sintered bodies.

Figure 11. $\mathrm{XRD}$ patterns of the (A) $\mathrm{B}_{4} \mathrm{C}-\mathrm{Co}$ and (B) $\mathrm{ZrC}-\mathrm{Co}$ composites obtained by pressureless sintering at $1700{ }^{\circ} \mathrm{C}$ for $2 \mathrm{~h}$ in Ar atmosphere. Peak assignations are included, in (A) only for relevant peaks up to $\sim 52.5^{\circ} 2 \theta$. The intensity scale in (A) is dominated by the atomic scattering factor of $\mathrm{Co}$, and the texture of $\mathrm{Co}_{2} \mathrm{~B}$.

Figure 12. Representative SEM images of the fracture surface of the broken (A) $\mathrm{B}_{4} \mathrm{C}-\mathrm{Co}$ and (B) $\mathrm{ZrC}-\mathrm{Co}$ compacts obtained by pressureless sintering at $1700{ }^{\circ} \mathrm{C}$ for $2 \mathrm{~h}$ in Ar atmosphere. 

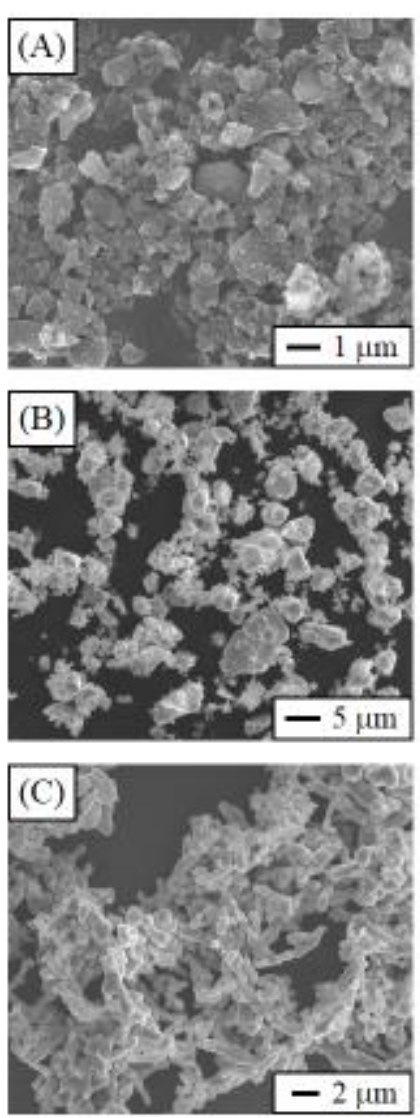

Ortiz ef al

Figure : 

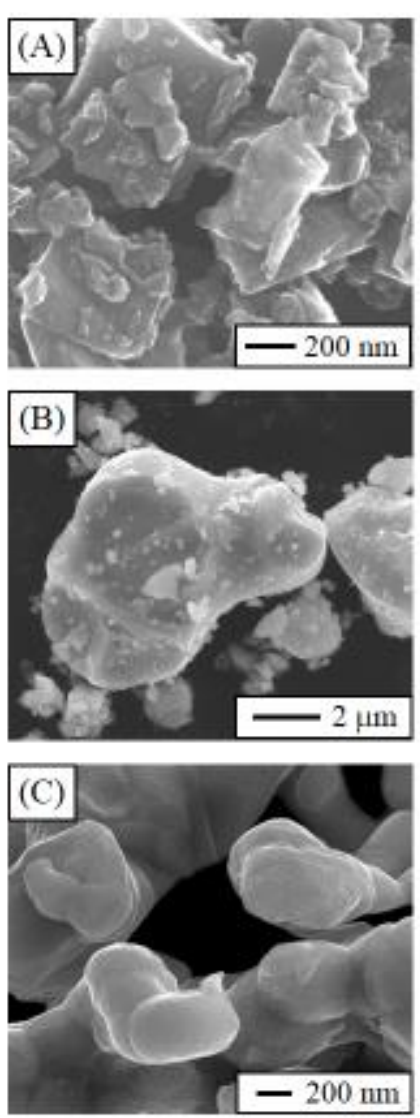

Ortiz ex al

Figure 2 


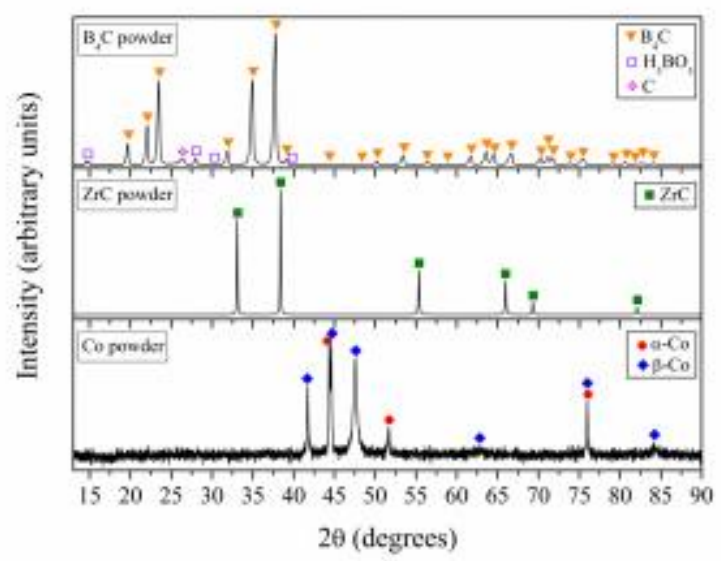

Ortiz at al

Figure 3 


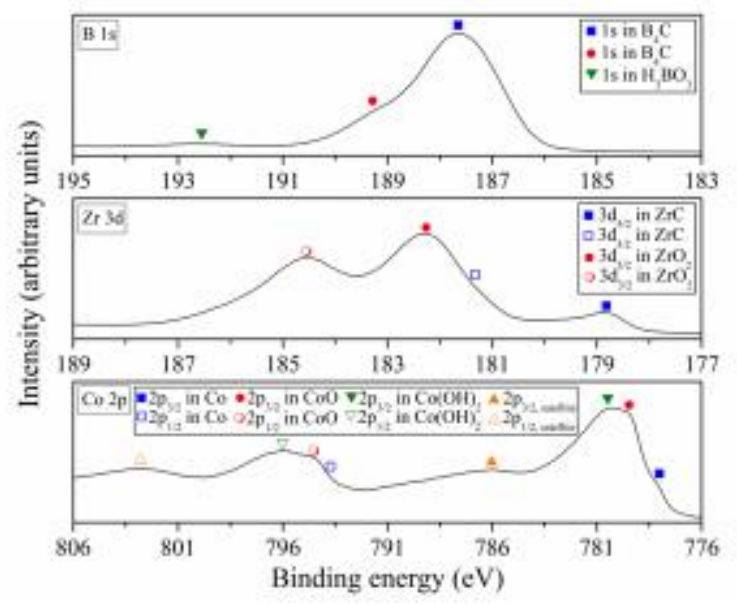

Ortiz at al

Figure 4 


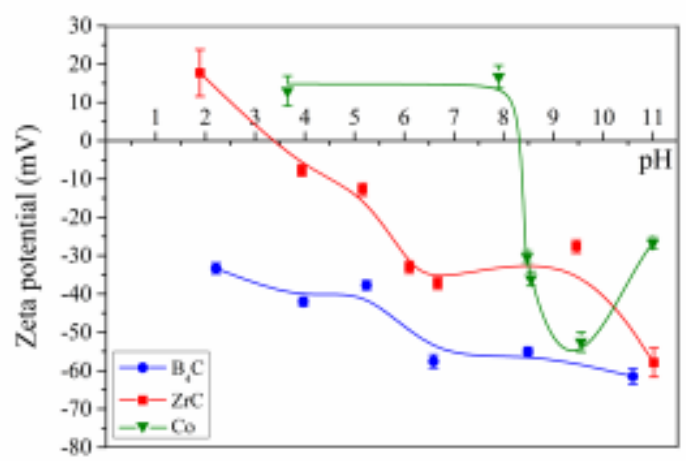

Ortiz at al

Figure 5 


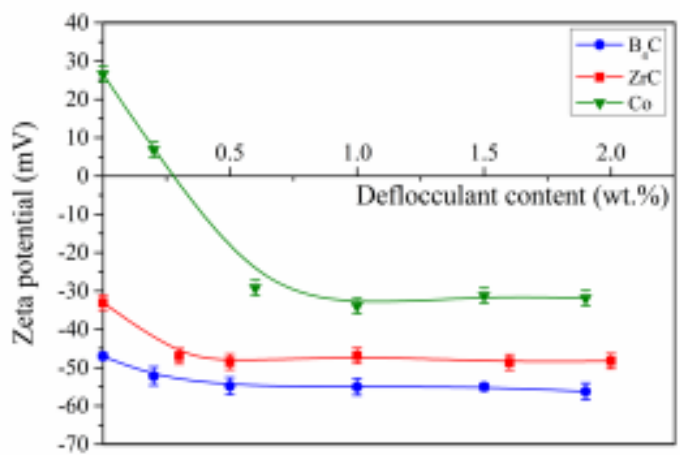

Ortiz et al

Figure 6 

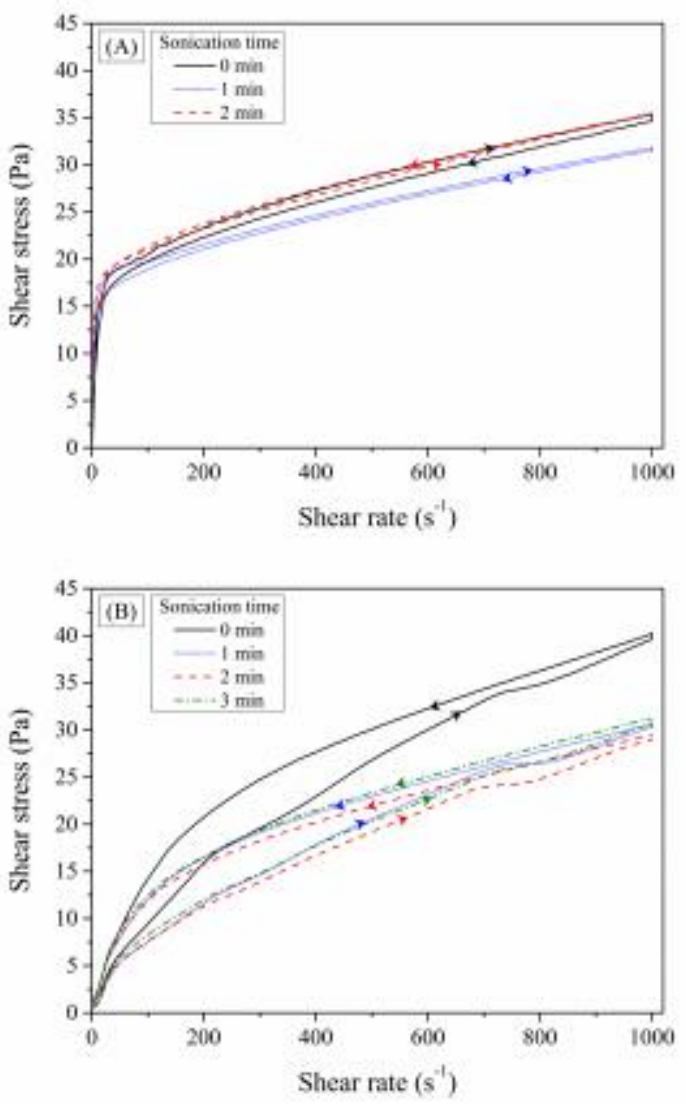

Ortiz ex al

Figure 7 


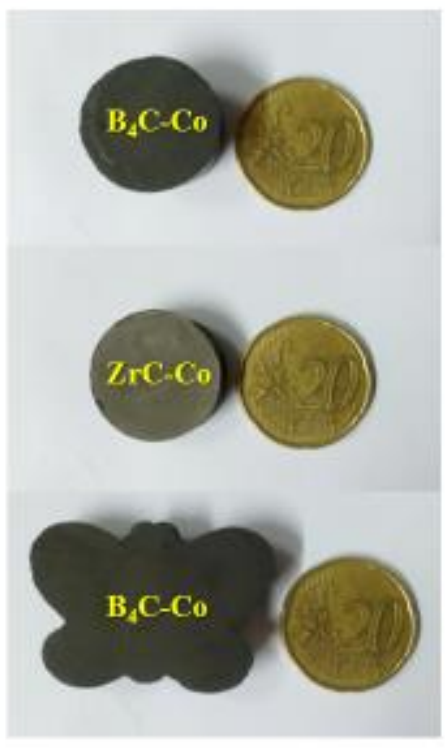

Ortiz et a

Figure 8 

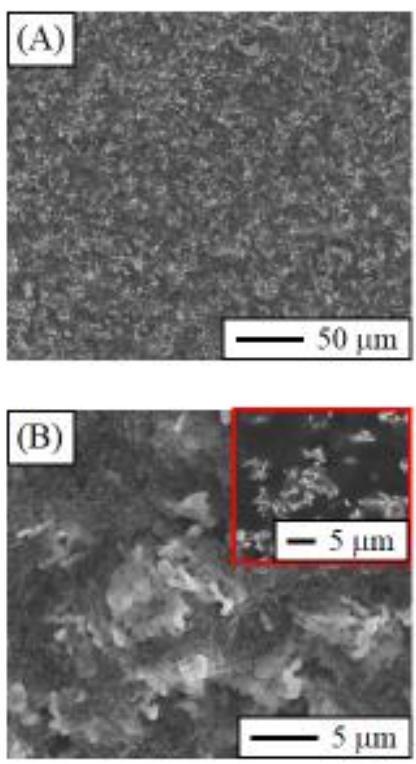

Ortiz et al

Figure 9 


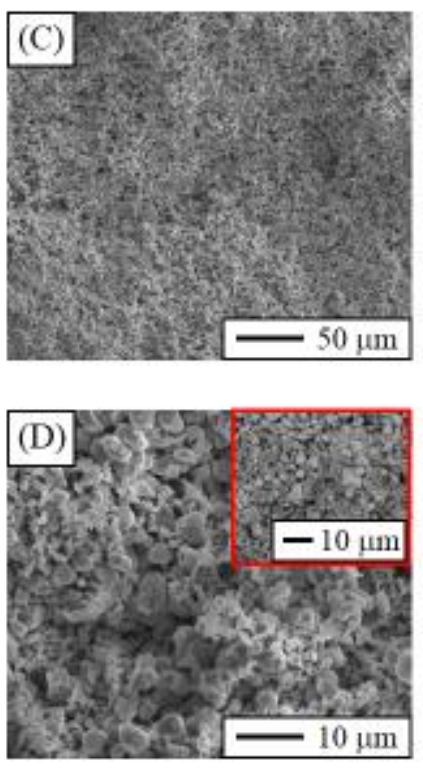

Ortiz et al

Figure 9 

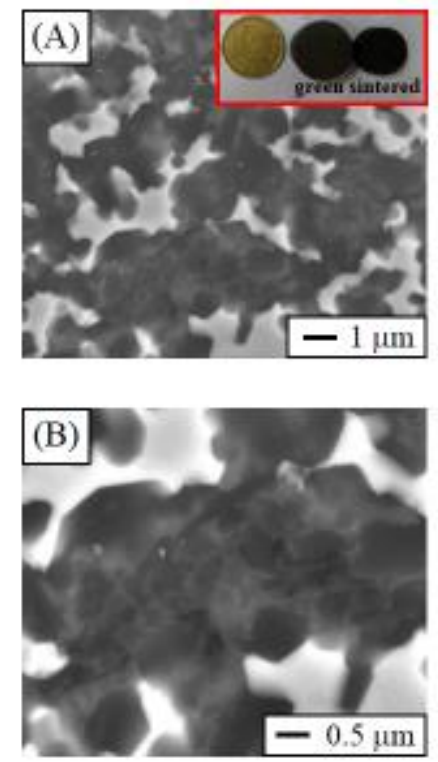

Ortiz et al

Figure 10 

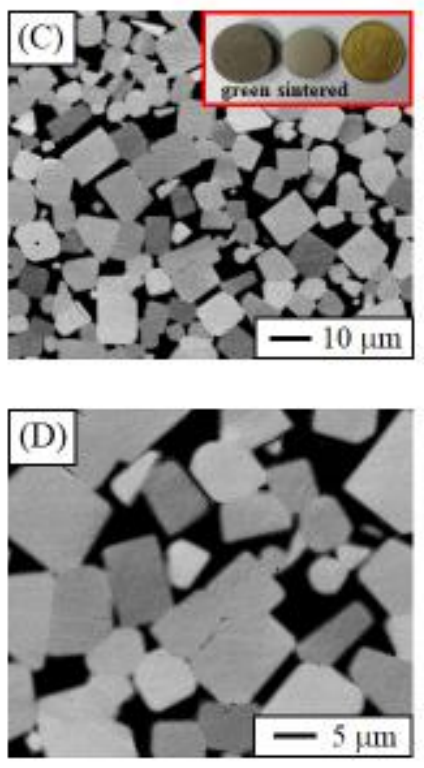

Ortiz et al

Figure 10 

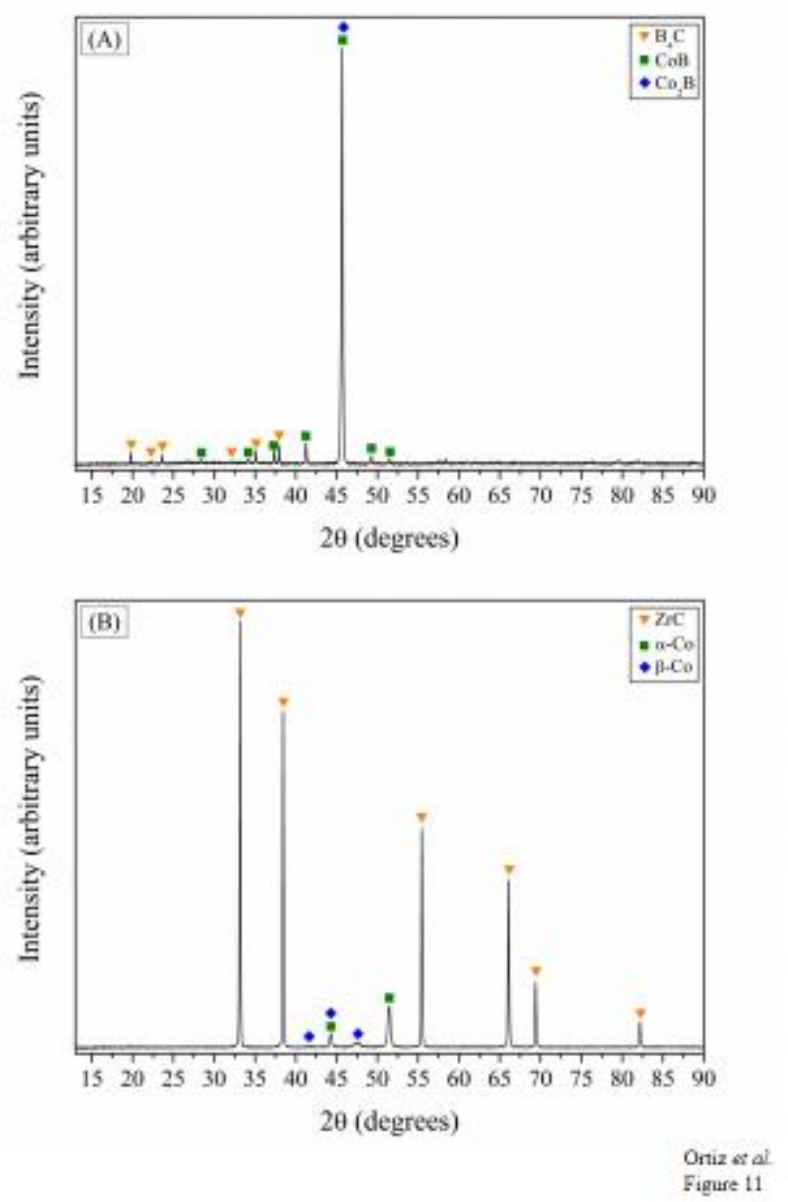

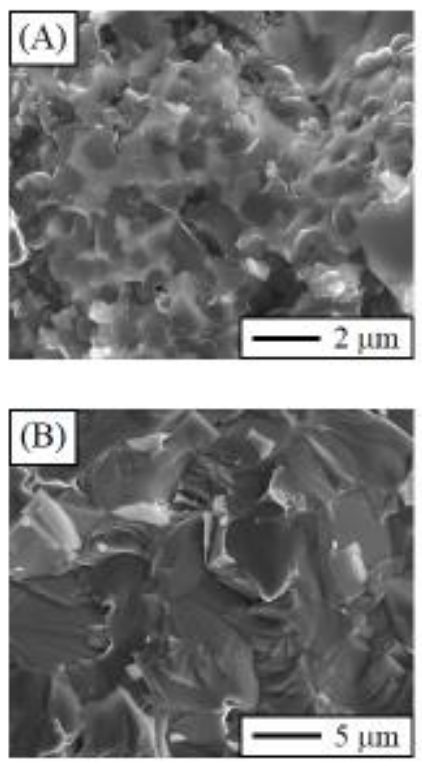

Ortiz et al

Figure 12 